\title{
FGD DAN EDUKASI TENTANG UPAYA PENCEGAHAN KEKERASAN SEKSUAL DALAM RUMAH TANGGA
}

\author{
Eko Raharjo ${ }^{1}$, Firganefi ${ }^{2}$, Maya Shafira ${ }^{3}$, Rini Fathonah ${ }^{4}$, Dona Raisa. M $^{5}$, Mashuril \\ Anwar*6 \\ 1,2,3,4,5,6Program Studi Ilmu Hukum, Fakultas Hukum, Universitas Lampung \\ *E-mail: mashuril.anwar97@gmail.com
}

\begin{abstract}
Sexual violence is generally identical to women. In the context of family life as the smallest institution, sexual violence often occurs. Therefore, it is necessary to give understanding to the community, especially the PKK drive team in Batanghari Nuban East Lampung District about the importance of prevention of sexual violence in households to realize the resilience of families and Country. The efforts undertaken in this activity are to provide knowledge and understanding of the law on the prevention of sexual violence in households to the community, especially the PKK Mobilizer team Batanghari Nuban East Lampung District. Then proceed with discussion and question and answer, and test participants ' understanding by providing pre test and post test. The results showed that the focus group discussion $(F G D)$ and education activities are important to do to improve the understanding and awareness of public law in preventing household sexual violence.
\end{abstract}

Keywords - FGD and education, prevention, sexual violence, household

\begin{abstract}
Abstrak
Kekerasan seksual pada umumnya identik dengan perempuan. Dalam konteks kehidupan keluarga sebagai institusi terkecil, kekerasan seksual sering terjadi. Oleh karena itu, perlu diberikan pemahaman kepada masyarakat khususnya Tim Penggerak PKK Kecamatan Batanghari Nuban Kabupaten Lampung Timur mengenai pentingnya pencegahan terhadap kekerasan seksual dalam rumah tangga untuk mewujudkan ketahanan keluarga dan negara. Upaya yang dilakukan dalam kegiatan ini yakni memberikan pengetahuan dan pemahaman hukum tentang pencegahan kekerasan seksual dalam rumah tangga kepada masyarakat khususnya Tim Penggerak PKK Kecamatan Batanghari Nuban Kabupaten Lampung Timur. Kemudian dilanjutkan dengan diskusi dan tanya jawab, serta menguji pemahaman peserta dengan memberikan pre test dan pos test. Hasil kegiatan menunjukan bahwa kegiatan focus group discussion (FGD) dan edukasi ini penting untuk dilakukan guna meningkatkan pengatahuan, pemahaman dan kesadaran hukum masyarakat dalam mencegah kekerasan seksual dalam rumah tangga.
\end{abstract}

Kata kunci-FGD dan edukasi, pencegahan, kekerasan seksual, rumah tangga

\section{PENDAHULUAN}

Posisi perempuan dalam kehidupan rupanya belum setara dengan laki-laki. 90\% perempuan pernah mengalami kekerasan bahkan dialami dirumah sendiri [1]. Berbagai persitiwa dewasa ini telah menunjukan diskriminasi terhadap perempuan [2]. Salah satu faktanya ialah maraknya kekerasan seksual yang dialami kaum hawa. Harkristuti dan Aroma Elmina mengatakan bahwa kekerasan seksual adalah setiap penyerangan seksual baik yang telah terjadi persetubuhan atau belum [3]. Kekerasan seksual merupakan tindak kekerasan yang sering dialami oleh kalangan perempuan [4]. Kekerasan seksual di Indonesia mengalami peningkatan setiap tahunnya [5]. Tingkah laku kriminal kekerasan seksual di Indonesia memiliki tingkat kuantitas yang cukup tinggi terutama terhadap anak dan perempuan. Kekerasan seksual terhadap perempuan merupakan tindakan yang tidak manusiawi yang melanggar hak asasi perempuan [6]. Dampak kekerasan seksual cenderung menyebankan kondisi traumatis terhadap korban [7]. Kekerasan seksual adalah 
termasuk, tetapi tidak terkecuali pada perkosaan, perbudakan seksual, perdagangan orang untuk eksploitasi seksual, pelecehan seksual, sterilisasi paksa, pengambilan paksa dan prostitusi paksa. Bisa dikatakan cukup tragis memang, perempuan yang identik dengan sosok yang lemah yang patut dilindungi malah mengalami kekerasan seksual [8]. Pasal 1 angka 1 UU No. 23 Tahun 2004 tentang Penghapusan Kekerasan Dalam Rumah Tangga (UU KDRT) pada intinya menyatakan bahwa kekerasan dalam rumah tangga adalah perbuatan terhadap seseorang terutama perempuan, yang berakibat timbulnya kesengsaraan atau penderitaan secara fisik, seksual, psikologis, dan/atau penelantaran rumah tangga termasuk ancaman untuk melakukan perbuatan, pemaksaan, atau perampasan kemerdekaan dalam rumah tangga. Berdasarkan ketentuan diatas, kekerasan seksual merupakan salah satu jenis kekerasan dalam rumah tangga yang pada umumnya dialami oleh perempuan (istri).

Kekerasan seksual dapat mengancam siapa saja tanpa mengenal usia, kelamin dan status[9]. Bahkan kekerasan seksual dewasa ini dialami oleh kalangan perempuan (isteri) dalam lingkungan keluarga. Jhonson dan Sacco menyatakan kekerasan seksual terhadap perempuan yang dilakukan oleh suaminya disebut dengan istilah wife abuse. Pada umumnya, kekerasan seksual terhadap istri yang terjadi dalam rumah tangga lebih dikenal oleh masyarakat umum disebut dengan istilah marital rape atau diartikan secara harfiah adalah pemerkosaan dalam rumah tangga sebab terdapat unsur-unsur pemaksaan seksual yang berdampak negatif bagi istri [10]. Marital Rape sendiri merupakan suatu istilah yang berkembang di masyarakat dimana dianggap telah terjadi pemerkosaan dalam rumah tangga atau yang terjadi dalam perkawinan dimana pada posisi seorang suami yang memaksa dengan kekerasan pada istrinya untuk melakukan hubungan seksual pada saat istri tidak menghendakinya atau di saat istri tidak menghendaki melakukan hubungan seksual dengan cara-cara yang tidak wajar atau tidak disukai istri. Kekerasan seksual pada umumnya sangat berhubungan dengan kekerasan terhadap perempuan. Dalam konteks kekerasan terhadap perempuan ini, ada banyak fakta yang telah terjadi di Indonesia yang mengakibatkan korban perempuan yang mengalami kekerasan semakin meningkat. Salah satu bentuk konkret dari kekerasan terhadap perempuan adalah kekerasan seksual. Kekerasan seksual adalah segala serangan yang mengarah pada seksualitas seseorang (baik laki-laki maupun perempuan) yang dilakukan dibawah tekanan. Kekerasan seksual adalah termasuk, tetapi tidak terkecuali pada perkosaan, perbudakan seksual, perdagangan orang untuk eksploitasi seksual, pelecehan seksual, sterilisasi paksa, pengambilan paksa dan prostitusi paksa. Kekerasan seksual terhadap istri yang terjadi dalam rumah tangga lebih dikenal oleh masyarakat umum disebut dengan istilah marital rape atau diartikan secara harfiah adalah pemerkosaan dalam rumah tangga.

Kekerasan seksual pun acap kali terjadi pada kehidupan keluarga sebagai institusi terkecil. Suatu keluarga merupakan tempat paling rawan bagi munculnya tindak kekerasan terhadap perempuan khususnya kekerasan terhadap istri. Kekerasan yang dilakukan suami terhadap istri atau yang dikenal dengan kekerasan dalam rumah tangga adalah salah satu bentuk kekerasan terhadap perempuan yang banyak terjadi di masyarakat. Kekerasan seksual terhadap istri berakibat pada kesengsaraan dan penderitaan secara fisik, seksual dan psikologis termasuk ancaman tindakan tertentu, pemaksaan atau perampasan kemerdekaan secara sewenang-wenang baik yang ada di depan umum atau dalam lingkungan pribadi. Kekerasan seksul dalam rumah tangga ibarat gunung es, banyak kasus namun sedikit yang terungkap [11]. Sebagian besar isteri yang menjadi korban tidak melapor pada pihak yang berwajib dikarenakan malu dan khawatir dengan ketahanan rumah tangganya. Hal ini didukung oleh pendapat Saraswati, bahwa apabila isteri yang mengalami kekerasan dalam rumah tangga menempuh jalur hukum maka akan berakhir pada perceraian [12]. Padahal kekerasan seksual dapat berdampak buruk seperti depresi, HIV/AIDS atau bahkan kematian [13]. Oleh karena itu, dibutuhkan perempuan yang berani mengungkapkan kekerasan seksual yang dialaminya agar perkawinan terhindar dari kekerasan dalam rumah tangga. Perempuan harus mampu membicarakan konflik dalam rumah tangga tanpa harus mengalami kekerasan. [14] Disamping itu, penegakan hukum terhadap kekerasan dalam rumah tangga termasuk kekerasan seksual dirasa masih kurang. Hal ini tidak lain karena kekerasan seksual adalah masalah di ranjang dan sangat pribadi sehingga jarang adanya laporan dari korban (isteri) [15]. Sebagai institusi terkecil dalam kehidupan masyarakat, kekerasan seksual dalam rumah tangga berimplikasi buruk terhadap ketahanan keluarga dan ketahanan negara. Oleh karena itu, 
perlu diberikan pemahaman kepada masyarakat mengenai pentingnya upaya pencegahan terhadap kekerasan seksual dalam rumah tangga untuk mewujudkan ketahanan keluarga dan negara.

\section{METODE}

Kegiatan ini dilakukan dengan menggunakan metode ceramah, diskusi dan tanya jawab. Penggunaan metode ceramah sabanyak $50 \%$, diskusi $25 \%$ dan tanya jawab $25 \%$. Metode ini digunkan agar materi yang disampaikan mudah dipahami oleh peserta. Selain itu, untuk menguji pemahaman peserta juga diberikan soal pre test dan post test. Tim menyampaikan materi dengan cara ceramah dengan menggunakan LCD yang sudah disiapkan sebelumnya, peserta sangat antusias dan serius menyimak serta memperhatikan dan mendengarkan dengan seksama di dalam kegiatan penyuluhan hukum ini. Kemudian dilanjutkan dengan diskusi dan tanya jawab antara peserta dengan pemateri mengenai penanggulangan perdagangan orang pada masyarakat Raman Utara Kabupaten Lampung Timur. Metode dalam pelaksanaan kegiatan Focus Group Discussion (FGD) Dan Edukasi Tentang Upaya Pencegahan Terhadap Kekerasan Seksual Dalam Rumah Tangga Dalam Rangka Mewujudkan Ketahanan Keluarga Dan Negara Pada Tim Penggerak PKK Kecamatan Batanghari Nuban Kabupaten Lampung Timur sebagai berikut:

1. Tim menyampaikan materi dengan cara menggunakan LCD yang sudah disiapkan sebelumnya, perserta sangat antusias dan serius menyimak serta memperhatikan dan mendengarkan dengan seksama di dalam kegiatan Focus Group Discussion (FGD) ini.

2. Diskusi dan tanya jawab mengenai hak-hak mereka untuk memperoleh pengetahuan tentang kekerasan seksual dalam rumah tangga dan Undang- Undang No. 23 Tahun 2004 tentang Penghapusan KDRT.

\section{HASIL DAN PEMBAHASAN}

Pengabdian kepada masyarakat ini lebih menitikberatkan kemampuan dari Tim Penggerak PKK Kecamatan Batanghari Nuban Kabupaten Lampung Timur dalam Upaya Pencegahan Terhadap Kekerasan Seksual Dalam Rumah Tangga Dalam Rangka Mewujudkan Ketahanan Keluarga Dan Negara. Khalayak sasaran yang hadir dalam kegiatan ini berjumlah 50 orang yang terdiri dari Tim Penggerak PKK dan aparat pemerintahan desa se-Kecamatan Batanghari Nuban. Sebagian besar dari masyarakat Kecamatan Batanghari Nuban bekerja sebagai petani, sehingga pemahaman mereka tentang Kekerasan Seksual Dalam Rumah Tangga masih simpang siur. Berdasarkan hasil evaluasi awal, proses dan akhir terhadap khlayak sasaran peserta kegiatan ini berhasil dengan baik. Keberhasilan ini ditandai dengan antusiasme masyarakat mengikuti kegiatan ini dibuktikan dengan kehadiran 50 orang peserta. Selain itu, para peserta aktif baik dalam bertanya maupun dalam berdiskusi mengenai Upaya Pencegahan Terhadap Kekerasan Seksual Dalam Rumah Tangga.

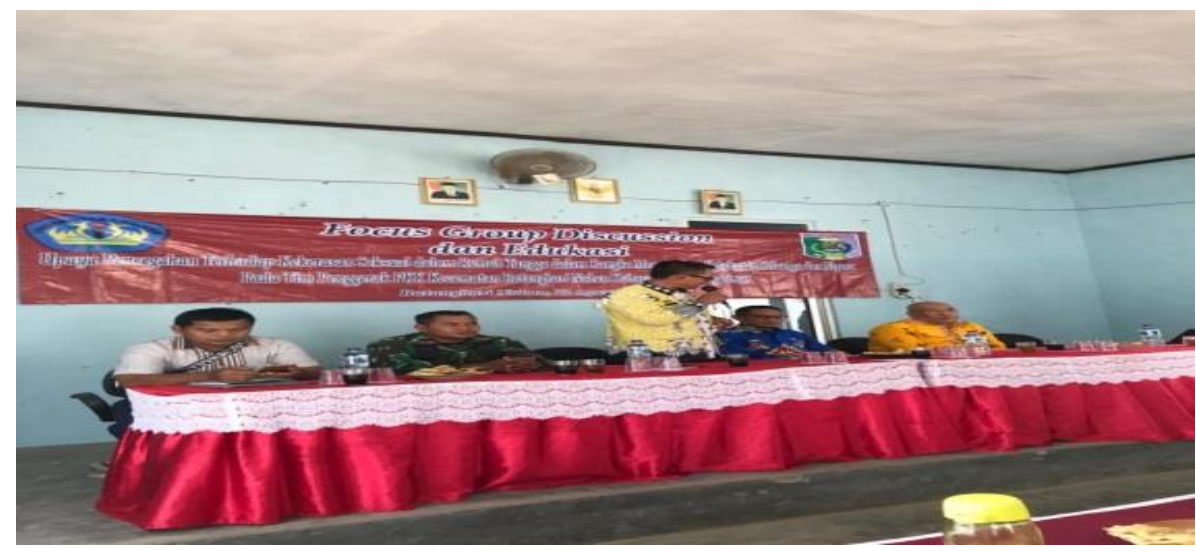

Gambar. 1 Pembukaan Kegiatan Pengabdian Oleh Camat Batanghari Nuban 
DINAMISIA - Jurnal Pengabdian Kepada Masyarakat Vol. 3, No. 2 Desember 2019, Hal. 198-204

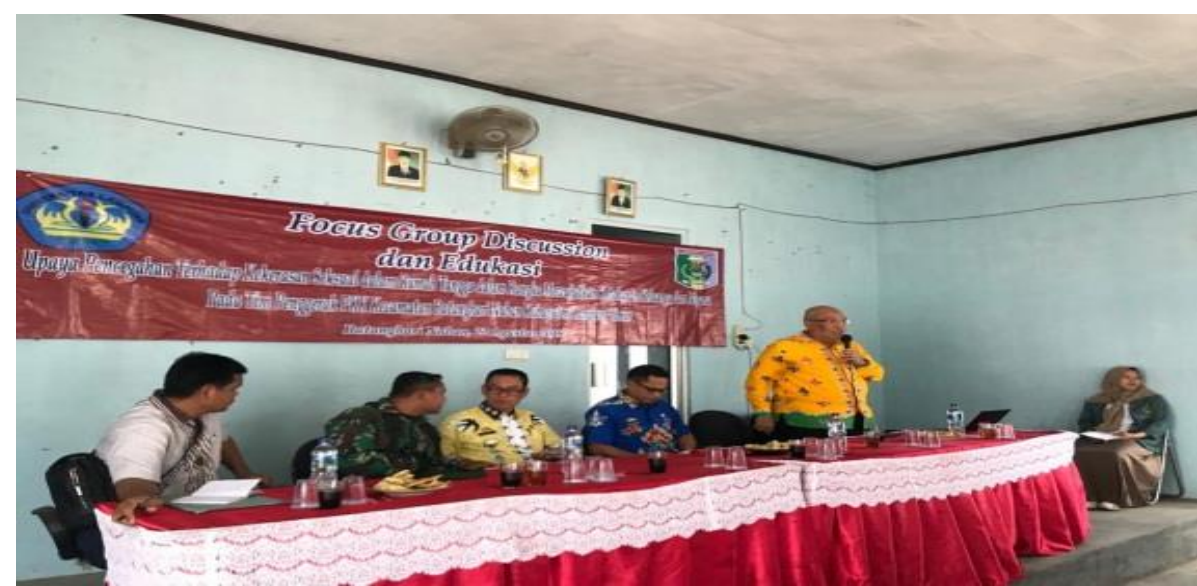

Gambar. 2 Sambutan Ketua Pelaksana Pengabdian

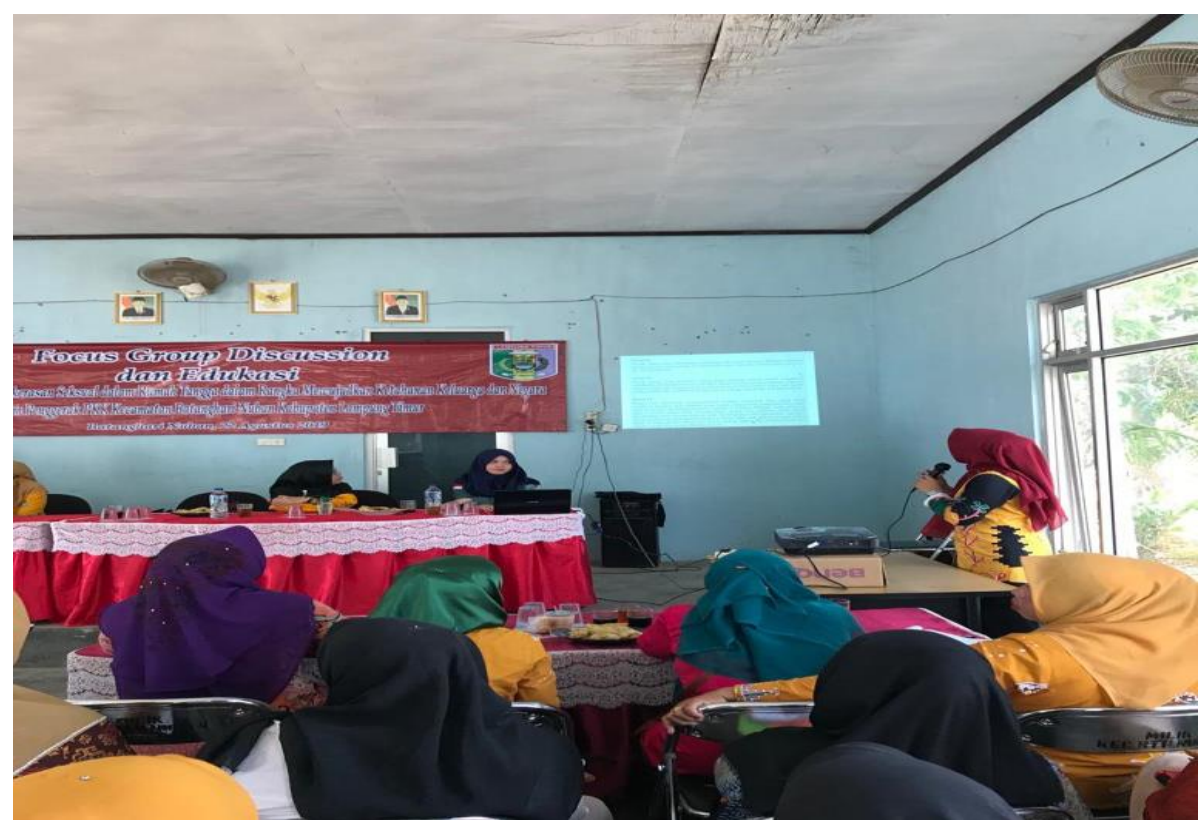

Gambar.3 FGD dan Edukasi mengenai Pencegahan Kekerasan Seksual dalam Rumah Tangga

Tabel 1. Perbandingan pra penyampaian materi dan pasca penyampaian materi Focus Group Discussion (FGD) Dan Edukasi Tentang Upaya Pencegahan Terhadap Kekerasan Seksual Dalam Rumah Tangga Dalam Rangka Mewujudkan Ketahanan Keluarga Dan Negara Pada Tim Penggerak PKK Kecamatan Batanghari Nuban Kabupaten Lampung Timur

\begin{tabular}{llcc}
\hline No & \multicolumn{1}{c}{ Unsur } & $\begin{array}{c}\text { Pra Penyampaian } \\
\text { Materi }\end{array}$ & $\begin{array}{c}\text { Pasca Penyampaian } \\
\text { Materi }\end{array}$ \\
\hline 1 & $\begin{array}{l}\text { Kekerasan seksual dalam rumah } \\
\text { tangga }\end{array}$ & Belum mengetahui & Sudah mengetahui \\
\hline 2 & $\begin{array}{l}\text { Pencegahan kekerasan seksual } \\
\text { dalam rumah tangga }\end{array}$ & Belum mengetahui & Sudah mengetahui \\
\hline 3 & $\begin{array}{l}\text { Penanggulangan kekerasan } \\
\text { seksual dalam rumah tangga }\end{array}$ & Belum mengetahui & Sudah mengetahui \\
\hline
\end{tabular}

Berdasarkan tabel diatas, pelaksanaan evaluasi dan hasilnya adalah sebagai berikut: 
1. Evaluasi awal sebelum penyampaian materi

Sebelum menyampaikan materi, tim pelaksana memberikan beberapa pertanyan terkait dengan kekerasan seksual dalam rumah tangga. Hal tersebut dimaksudkan untuk mengetahui tingkat pengetahuan dan pemahaman masyarakat mengenai kekerasan seksual dalam rumah tangga. Hasil evaluasi awal mengenai pegetahuan dan pemahaman masyarakat tentang kekerasan seksual dalam rumah tangga, menunjukan bahwa 80\% masyarakat belum sepenuhnya mengetahui dan memahami kekerasan seksual dalam rumah tangga, instrumen hukum yang mengaturnya, perlindungan hukum korban kekerasan seksual dalam rumah tangga dan penanggulangan kekerasan seksual dalam rumah tangga.

Sebelum dilakukan penyampain materi, peserta belum mengetahui bahwa kekerasan seksual dalam rumah tangga dapat dipidana. Mereka juga belum mengetahui dan memahami bagaimana pencegahan dan penanggulangannya. Hal ini dapat dilihat dari hasil pre-test yang dilakukan, dimana $80 \%$ peserta belum memahami kekerasan seksual dalam rumah tangga. Dari hasil pretest, ditemukan $50 \%$ peserta menjawab bahwa penyebab terjadinya kekerasan dalam rumah tangga adalah:

1) Kemiskinan;

2) Rendahnya pendidikan;

3) Komunikasi yang buruk;

4) Tidak ada kesepahaman dan pengertian;

5) Minimnya pengetahuan dan pemahaman nilai-nilai agama;

Sedangkan pengetahuan masyarakat khususnya Tim Penggerak PKK Kecamatan Batanghari Nuban tentang cara melakukan pencegahan dan penanggulangan kekerasan seksual dalam rumah tangga masih minim. Bahkan $80 \%$ peserta tidak mengetahui perbuatan seperti apa yang dapat dikategorikan sebagai kekerasan seksual dalam rumah tangga. Berdasarkan hasil pre-test, selama ini peserta hanya menerima saja perlakuan keras suami dalam memenuhi hasrat seksnya.

2. Evaluasi proses pelaksanaan

Evaluasi proses pelaksanaan dilakukan dengan melihat partisipasi serta keaktifan peserta dalam kegiatan Focus Group Discussion (FGD) Dan Edukasi Tentang Upaya Pencegahan Terhadap Kekerasan Seksual Dalam Rumah Tangga Dalam Rangka Mewujudkan Ketahanan Keluarga Dan Negara Pada Tim Penggerak PKK Kecamatan Batanghari Nuban Kabupaten Lampung Timur Timur sedang berlangsung. Berdasarkan hasil pengamatan tim pelaksana pengabdian, pasrtisipasi dan keaktifan peserta cukup tinggi, hal ini ditunjukan dengan adanya beberapa pertanyaan yang diajukan peserta kepada para narasumber serta aktif dalam termin diskusi dan tanya jawab. Pada saat penyampaian materi dan diskusi serta tanya jawab, peserta cukup antusias dan terlihat keinginan mereka untuk memahami materi tentang kekerasan seksual dalam rumah tangga, cara pencegahan dan penanggulangannya. Antusiasme peserta ini tentu wajar, mengingat materi yang disampaikan pun berbobot dan langsung oleh ahlinya.

3. Evaluasi akhir

Evaluasi akhir dilaksanakan oleh tim pengabdian dengan mengadakan diskusi dan tanya jawab serta memberikan beberapa pertanyaan post-test dan melakukan review terhadap jawaban peserta. Evaluasi ini dimaksudkan untuk mengetahui keberhasilan kegiatan Focus Group Discussion (FGD) Dan Edukasi Tentang Upaya Pencegahan Terhadap Kekerasan Seksual Dalam Rumah Tangga Dalam Rangka Mewujudkan Ketahanan Keluarga Dan Negara Pada Tim Penggerak PKK Kecamatan Batanghari Nuban Kabupaten Lampung Timur. 
Diagram 1. Tingkat pemahaman masyarakat mengenai kekerasan seksual dalam rumah tangga

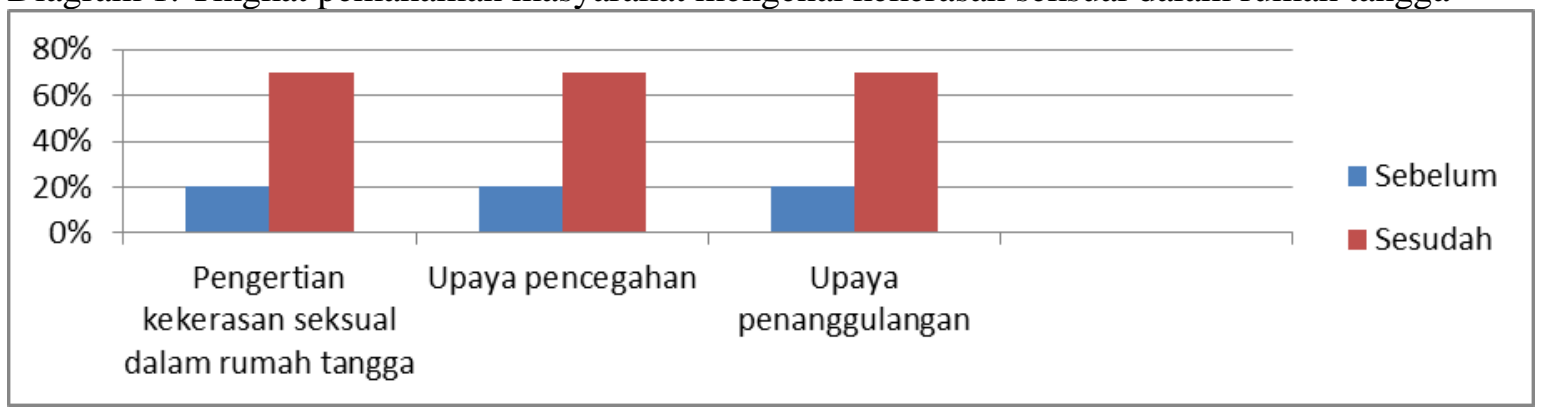

Berdasarkan hasil evaluasi akhir, dapat diketahui bahwa telah ada peningkatan pengetahuan dan pemahaman hukum masyarakat terutama Tim Penggerak PKK Kecamatan Batanghari Nuban mengenai kekerasan seksual dalam rumah tangga. Secara perlahan masyarakat mulai memahami apa itu kekerasan seksual, sebab terjadinya kekerasan seksual, cara pencegahan dan penanggulannya. Berdasarkan hasil pertanyaan post-test, tingkat pemahaman masyarakat mengenai tindak pidana perdagangan orang meningkat menjadi $70 \%$. Secara umum masyarakat cukup antusias, namun sasaran pengabdian ini yakni Tim Penggerak PKK kurang aktif dalam diskusi dan tanya jawab dengan pemateri. Peserta merasa puas karena materi yang disampaikan sangat jelas, mudah dipahami dan bermanfaat. Dari hasil pertanyaan post-test dapat diketahui juga bahwa $90 \%$ peserta terkesan senang dan menanggap bahwa kegiatan sangat perlu dilakukan untuk menambah pengatahuan dan menginginkan kegiatan Focus Group Discussion (FGD) Dan Edukasi Tentang Upaya Pencegahan Terhadap Kekerasan Seksual Dalam Rumah Tangga Dalam Rangka Mewujudkan Ketahanan Keluarga Dan Negara Pada Tim Penggerak PKK Kecamatan Batanghari Nuban Kabupaten Lampung Timur dilakukan kembali.

\section{KESIMPULAN}

Berdasarkan hasil dan pembahasan kegiatan Focus Group Discussion (FGD) Dan Edukasi Tentang Upaya Pencegahan Terhadap Kekerasan Seksual Dalam Rumah Tangga Dalam Rangka Mewujudkan Ketahanan Keluarga Dan Negara Pada Tim Penggerak PKK Kecamatan Batanghari Nuban Kabupaten Lampung Timur diatas, maka dapat disimpulkan bahwa kegiatan Focus Group Discussion (FGD) Dan Edukasi Tentang Upaya Pencegahan Terhadap Kekerasan Seksual Dalam Rumah Tangga Dalam Rangka Mewujudkan Ketahanan Keluarga Dan Negara Pada Tim Penggerak PKK Kecamatan Batanghari Nuban Kabupaten Lampung Timur telah memberikan pengetahuan dan pemahaman kepada para peserta mengenai kekerasan seksual dalam rumah tangga. Hal ini dapat dilihat dari hasil evaluasi, bahwa ada peningkatan pengetahuan dan pemahaman hukum peserta. Secara perlahan masyarakat mulai memahami apa itu kekerasan seksual, sebab terjadinya, cara pencegahan dan penanggulannya.

\section{SARAN}

Kepada Pimpinan Universitas Lampung khususnya Lembaga Penelitian dan Pengabdian Kepada Masyarakat (LPPM), kegiatan penyuluhan hukum perlu ditingkatkan lagi secara berlanjut dan berkesinambungan guna memberikan pengetahuan dan pemahaman hukum kepada masyarakat khususnya mengenai tindak pidana perdagangan orang.

\section{UCAPAN TERIMA KASIH}

Penulis mengucapkan terima kasih kepada Universitas Lampung yang telah mendanai PKM FGD dan edukasi tentang upaya pencegahan terhadap kekerasan seksual dalam rumah tangga tahun anggaran 2019. 


\section{DAFTAR PUSTAKA}

[1] Kurnianingsig, Sri, 2015, Pelecehan Seksual Terhadap Perempuan Di Tempat Kerja, Buletin Psikologi, https://doi.org/10.22146/bpsi.7464.

[2] Harkrisnowo, H, 2000, Tindakan Kekerasan terhadap Perempuan dalam Perspektif SosioYuridis, Jurnal Hukum IUS QUIA IUSTUM, https://doi.org/10.20885/iustum.vol7.iss14.art11.

[3] Hartati, M, 2013, Studi tentang upaya penanganan tindak kekerasan terhadap perempuan dan anak (Studi kasus pada pusat pelayanan terpadu pemberdayaan perempuan dan anak (P2TP2A) Provinsi Kalimantan Timur)), Ejournal Fisip Unmul.

[4] Pasalbessy, J. D, 2010, Dampak Tindak Kekerasan Terhadap Perempuan Dan Anak Serta Solusinya, Sasi.

[5] Ivo Noviana, 2013, Kekerasan Seksual Terhadap Anak, Jurnal Sosio Informa Vol. 1 No. 1, hlm. 14.

[6] Marcheyla Sumera, 2013, Perbuatan Kekerasan/Pelecehan Seksual Terhadap Perempuan, Jurnal Lex Societatis Vol. 1 No. 2, hlm. 39.

[7] Ratih Probosiwi dan Daud Bahransyaf, 2015, Pedofilia dan Kekerasan Seksual, Jurnal Sosio Informa Vol. 1 No. 1, hlm. 31.

[8] B. Rudi Harnoko, 2010, Dibalik Tindak Kekerasan Terhadap Perempuan, Jurnal Muwazah Vol. 1 No. 1, hlm. 181.

[9] M. Anwar Fuadi, 2011, Dinamika Psikologi Kekerasan Seksual, Jurnal Psikoislamika Vol. 8 No. 2, hlm. 192.

[10] Sari, A. A., \& Sularto, R. B, 2019, Kebijakan Formulasi Kekerasan Seksual Terhadap Istri (Marital Rape) Berbasis Keadilan Gender Di Indonesia, Jurnal Pembangunan Hukum Indonesia, https://doi.org/10.14710/jphi.v1i1.117-127

[11] Hidayati, N, 2014, Perlindungan Anak terhadap Kejahatan Kekerasan Seksual ( Pedofilia ), Jurnal Pengembangan Humaniora.

[12] Puspita Dewi, I. D. A. D., \& Hartini, N, 2017, Dinamika Forgiveness pada Istri yang Mengalami Kekerasan dalam Rumah Tangga (KDRT), INSAN Jurnal Psikologi Dan Kesehatan Mental, https://doi.org/10.20473/jpkm.v2i12017.51-62.

[13] Sutrisminah, E, 2012, Dampak Kekerasan Pada Istri Dalam Rumah Tangga Terhadap Kesehatan Reproduksi, Majalah Ilmiah Sultan Agung.

[14] Astuti, Puji, 2015, Kemandirian Dan Kekerasan Terhadap Istri, Buletin Psikologi. https://doi.org/10.22146/bpsi.7453.

[15] Widyastuti, A. Reni, 2012, Peran Hukum dalam Memberikan Perlindungan terhadap Perempuan dari Tindak Kekerasan di Era Globalisasi, Mimbar Hukum, https://doi.org/10.22146/jmh.16264. 